\title{
3D analysis of soft tissue around implant after flap folding suture
}

\author{
Sae-Young Jung ${ }^{1 \dagger}$, Dae-Young Kang ${ }^{2 \dagger}$, Hyun-Seung Shin', Jung-Chul Park* \\ 'Department of Periodontology, College of Dentistry, Dankook University, Cheonan, Republic of Korea \\ ${ }^{2}$ Department of Periodontology, Dankook University Dental Hospital, Cheonan, Republic of Korea
}

Purpose: The various suture techniques can be utilized in order to maximize the keratinized tissue healing around dental implants. The aim of this study is to compare the soft tissue healing pattern between two different suture techniques after implant placement. Materials and Methods: 15 patients with 18 implants were enrolled in this study. Simple implant placement without any additional bone graft was performed. Two different suture techniques were used to tug in the mobilized flap near the healing abutment after paramarginal flap design. Digital intraoral scan was performed at baseline, post-operation, stitch out, and 3 months after operation. The scan data were aligned using multiple points such as cusp, fossa of adjacent teeth, and/or healing abutment. After subtracting scan data at baseline with other time-point results, closed space indicating volume increment of peri-implant mucosa was selected. The volume of the close space was measured in $\mathrm{mm}^{3}$. The volume between two suture techniques at three time-points was compared using nonparametric rank-based analysis. Results: Healing was uneventful in both groups. Both suture technique groups showed increased soft tissue volume immediately after surgery. The amount of volume increment significantly decreased after 3 months $(P<0.001)$. Flap folding suture group showed higher median of volume increment than interrupted suture group after 3 months without any statistical significance $(P>0.05)$. Conclusion: After paramarginal flap reflection, the raised flaps stabilized by flap folding suture showed relatively higher volume maintenance after 3-month healing period. However, further studies are warranted. (J Dent Rehabil Appl Sci 2021;37(3):130-7)

Key words: dental implant; keratinized mucosa; sutures; intraoral scanner; clinical trial

\begin{abstract}
서론
임플란트의 건강을 유지하는 것에는 여러가지 변수들 이 기여를 하고 있으나 최근 주목받고 있는 것은 연조직 의 표현형, 그 중에서도 각화점막(keratinized mucosa, $\mathrm{KM}$ )의 존재 유무이다. 사실 임플란트 주변의 $\mathrm{KM}$ 의 존 재가 임플란트의 건강 유지에 중요하다는 것을 입증하 기에는 질 높은 연구가 부족한 것이 사실이다. ${ }^{1}$ 그럼에 도 불구하고 많은 연구들은 임플란트 주변 $\mathrm{KM}$ 확보 가 가지는 임상적 중요성을 반복해서 지적하고 있다. Wennström과 Derks는 임플란트 주변의 적절한 폭경의

\footnotetext{
*Correspondence to: Jung-Chul Park

Associate Professor, Department of Periodontology, College of Dentistry, Dankook University, 119 Dandae-ro, Dongnam-gu, Cheonan-si 31116, Republic of Korea Tel: +82-41-550-1931, Fax: +82-303-3442-7364, E-mail: back2thesuture@gmail.com Received: September 1, 2021/Last Revision: September 7, 2021/Accepted: September 7, 2021

+Shared co-first authorship.
}

$\mathrm{KM}$ 이 없다는 것이 임플란트 자체의 건강에 유해하지는 않지만 환자의 적절한 구강 위생 관리를 방해함으로써 결국 문제가 발생할 수 있다고 보고하였다. ${ }^{2} 10$ 년의 전향 적 연구에서 Roccuzzo 등은 $\mathrm{KM}$ 의 유무와 관련하여 건 강한 또는 중등도의 치주 손상 환자의 하악 구치에 식립 한 임플란트 주변의 임상 상태를 관찰한 결과 보고를 통 해 $\mathrm{KM}$ 으로 둘러싸이지 않은 임플란트는 충분한 구강 위생에도 불구하고 치태가 축적되고 치은 퇴축이 발생하 기 쉽다는 결론을 내렸다. ${ }^{3}$ 이러한 보고들을 근거로 임상 가들은 임플란트 식립 시에 $\mathrm{KM}$ 의 증강을 위해 다양한 술식을 시행하고 있다.

Copyright(C) 2021 The Korean Academy of Stomatognathic Function and Occlusion. (c) It is identical to Creative Commons Non-Commercial License. 
$\mathrm{KM}$ 증강에 가장 널리 쓰이는 방식은 유리치은이식술 (free gingival graft, FGG)이다. 임플란트 주위 점막의 변 연 부분을 부분층으로 박리한 뒤 구개측에서 채득한 유 리치은을 봉합으로 부분층 판막 위에 고정하면 안정적인 임플란트 주변 $\mathrm{KM}$ 을 확보할 수 있다. ${ }^{4}$ 하지만 이 술식 은 치유 후 주변 조직과의 색상 조화가 어렵다는 단점이 있어 전치부에서 시행하기에는 어려움이 있다. 이에 이를 대체하기 위한 3차원 체적 안정성 콜라겐 매트릭스 생체 재료를 유리치은 대신 사용하여 임플란트 주변에 $\mathrm{KM}$ 을 증강시키는 술식도 좋은 결과를 보고하였다. ${ }^{5}$ 무엇보다 콜라겐 매트릭스는 색상 조화에 있어 탁월한 결과를 보 이고 있으며 구개측 이식편 채득 과정이 생략되기 때문에 환자에게는 부가적인 수술의 불편감을 감소시킬 수 있 다. 다만 구개측 이식편 사용시와는 달리 부가적인 비용 부담이 발생한다는 단점이 있다.

임플란트 주변의 $\mathrm{KM}$ 을 수치를 증가시키되 별도의 복 잡한 술식이나 비용적인 부담을 줄일 수 있는 또 다른 방 식으로는 판막의 디자인을 통하는 방식이 있다. $\mathrm{KM}$ 의 폭이 직접적으로 증가하지는 않지만 최소한 연조직의 부 피를 증강시킴으로서 연조직의 외형을 재건할 수 있는 modified roll technique이 그 대표적인 예이다. ${ }^{6}$ 하지만 이 술식의 경우에는 탈상피화를 통한 결합조직의 노출 과정이 필수적이며 이후 협측 판막 안쪽으로 말아넣은 탈상피화된 판막부위를 안정적으로 고정하는데 있어 봉 합술의 도움이 필수적인데 좁은 시야에서 적절히 봉합술 을 시행하기가 쉽지 않다는 어려움이 있다.

본 연구에서는 특별한 이식의 절차 없이 환자의 기존 $\mathrm{KM}$ 을 최대한 활용하되 봉합을 통해 $\mathrm{KM}$ 을 안정적으로 유지하는 수술 방법의 효능에 대해 평가하고 기존 봉합 방법에 대비하여 비교 분석하였다.

\section{연구 재료 및 방법}

본 연구는 2019년 4월부터 2019년 6월까지의 기간 동 안 단국대학교 치과대학 치과병원 치주과에서 임플란트 수복을 위해 내원한 환자 중 본 임상 연구에 참여할 것 을 자발적으로 서면 동의한 환자를 대상으로 진행하였 다(IRB No. DKU-IRB 2019-06-005-001). 만 19세 이상 70세 미만의 악골의 성장이 완료된 성인 환자를 대상으 로 하였으며 시험대상자의 선정은 골이식술을 동반하지 않을 것으로 예상되는 임플란트 식립 환자로서 임플란트 수술에 일반적인 금기증을 가진 대상자는 제외하였다.
총 15 명에게서 18 개의 임플란트를 다음의 그룹 중 하나 로 무작위 배정하였다.

· 실험군: Flap folding suture (Fig. 1)

- 대조군: Interrupted suture를 근원심측에 각각 하나 씩 시행하여 판막을 고정한다.

골이식이 불필요한 임플란트 식립 증례에서 임플란 트 1차 수술을 진행하였다. 1:80,000 에피네프린을 포 함한 $2 \%$ 리도카인으로 국소 마취를 시행한 뒤 인접치 의 치은변연으로부터 $2 \mathrm{~mm}$ 정도 떨어져 paramarginal incision을 시행하였다. 이후 판막을 협측으로 전층 거 상하였고 통법에 의해 임플란트 식립을 진행하였다. 이 후 디지털 스캐너에 사용할 수 있도록 제작된 polyether ether ketone (PEEK) 스캔 바디 통합 치유 지대주(IOS abutment, Dentium, Suwon, South Korea)를 체결한 뒤 5-0 Ethilon ${ }^{\circledR}$ 봉합사(Ethicon Inc., J \& J Company, New Brunswick, USA)를 이용하여 각 실험군과 대조군에 해 당하는 서로 다른 2개의 방식으로 봉합을 하였다. Flap folding suture의 경우는 한번의 매듭으로 마무리하였다 (Fig. 2).

\section{디지털 구강 스캔}

연조직의 3차원 변화를 기록·계측하기 위해서 구내 디 지털 스캐너(i500, iScan version 1.2.0.1; Medit, Seoul, Korea)를 사용하였다. 모든 환자에게 동일한 방법으로 스캐닝을 진행하였다. 우선 술전에 근원심 인접치아 각각 3 개와 전정과 설측의 치은이 모두 포함되도록 스캔을 진

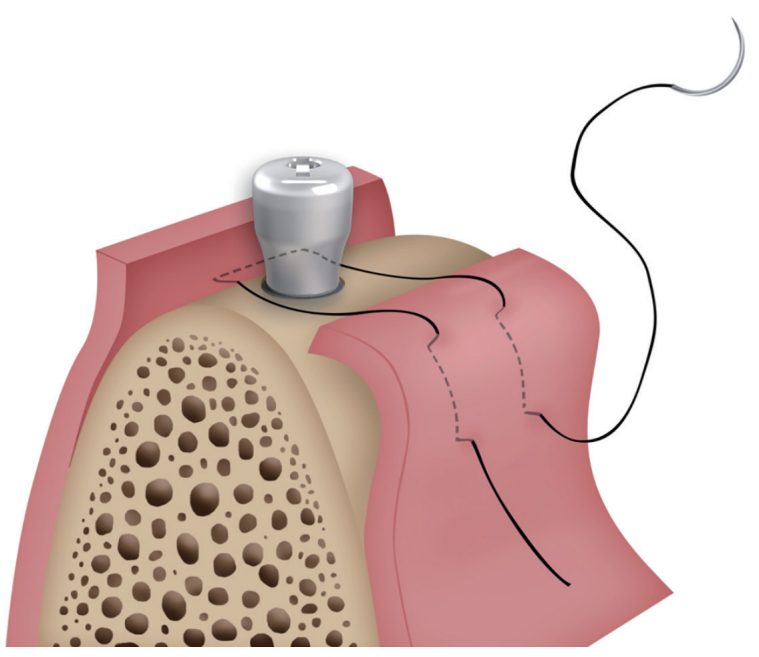

Fig. 1. Schematic illustration of flap folding suture. 
Fig. 2. Clinical photo of flap folding suture. (A) Before surgery, (B) Paramarginal flap design was performed and an implant fixture was placed, (C) Flap folding suture was performed and the mobilized flap is secured down, (D) 3-month healing.
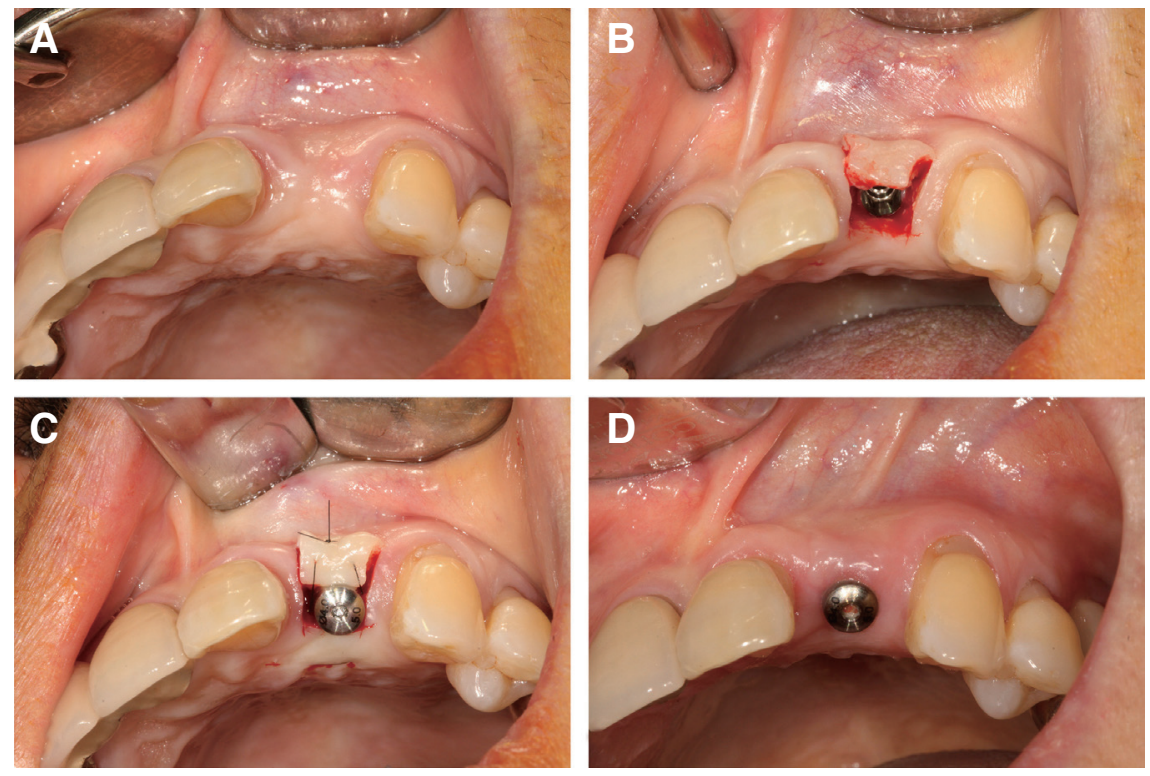

A

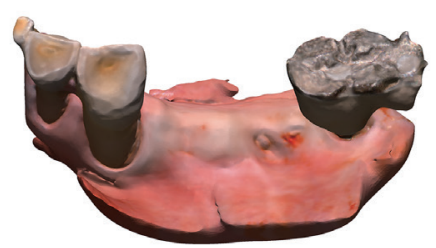

C

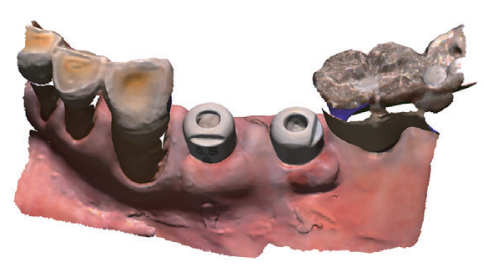

B

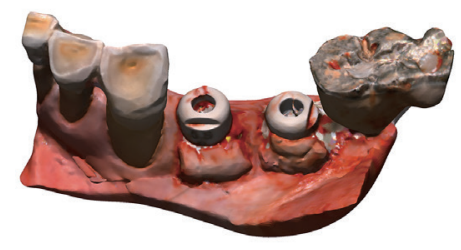

D

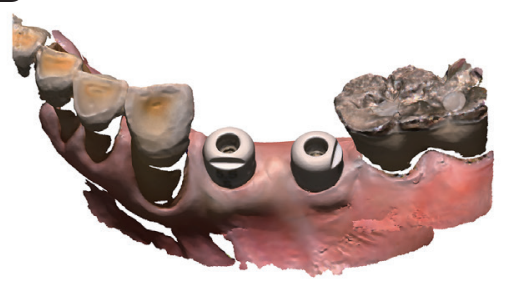

행하였다. 스캐닝을 진행하는 술자는 환자의 12 시 방향 에 위치하여 진행하고 우측손을 이용하였다. 측정의 신 뢰도를 위해 스캐닝은 숙련된 술자(J.C.P.)가 진행하였다. 스캐닝은 $21.0 \mathrm{~mm}$ 스캔 깊이와 레벨 1 필터링 세팅 환경 하에 진행하였다. 이후 수술 후, 2주 후 봉합사 제거, 3 개 월 후 반복적인 스캔을 진행하였다(Fig. 3).

\section{3차원 부피 계측}

디지털 스캐너를 이용해서 얻어진 스캔 데이터는 스 캐닝 프로그램(Medit link, Medit)을 통해 각각 polygon file format (.ply)의 파일로 추출되었다. 수술 전, 수술 후,
봉합사 제거, 3 개월 후 스캔 데이터를 이미지 분석 소프 트웨어(3-matic Medical 13.0, Materialize, Leuven, Belgium)를 이용하여 인접한 자연치의 교두, 소와, 치유 지 대주의 다수의 점을 기준점으로 하여 중첩하였다. 수술 후, 봉합사 제거 시, 3 개월 후의 3 개 시점의 스캔 데이터 에서 수술 전 스캔 데이터를 Boolean subtraction한 다음 standard tessellation language (.stl) 파일로 내보내기 하 였다. 이미지 분석 소프트웨어(Geomagic ${ }^{\circledR}$ Design $\mathrm{X}^{\mathrm{TM}}$, 3D systems Inc., Rock Hill, USA)를 이용하여 증가된 임 플란트 주위 연조직에 해당되는 3차원 폐곡면 공간을 선 택하고 그 부피를 측정하였다(Fig. 4). 

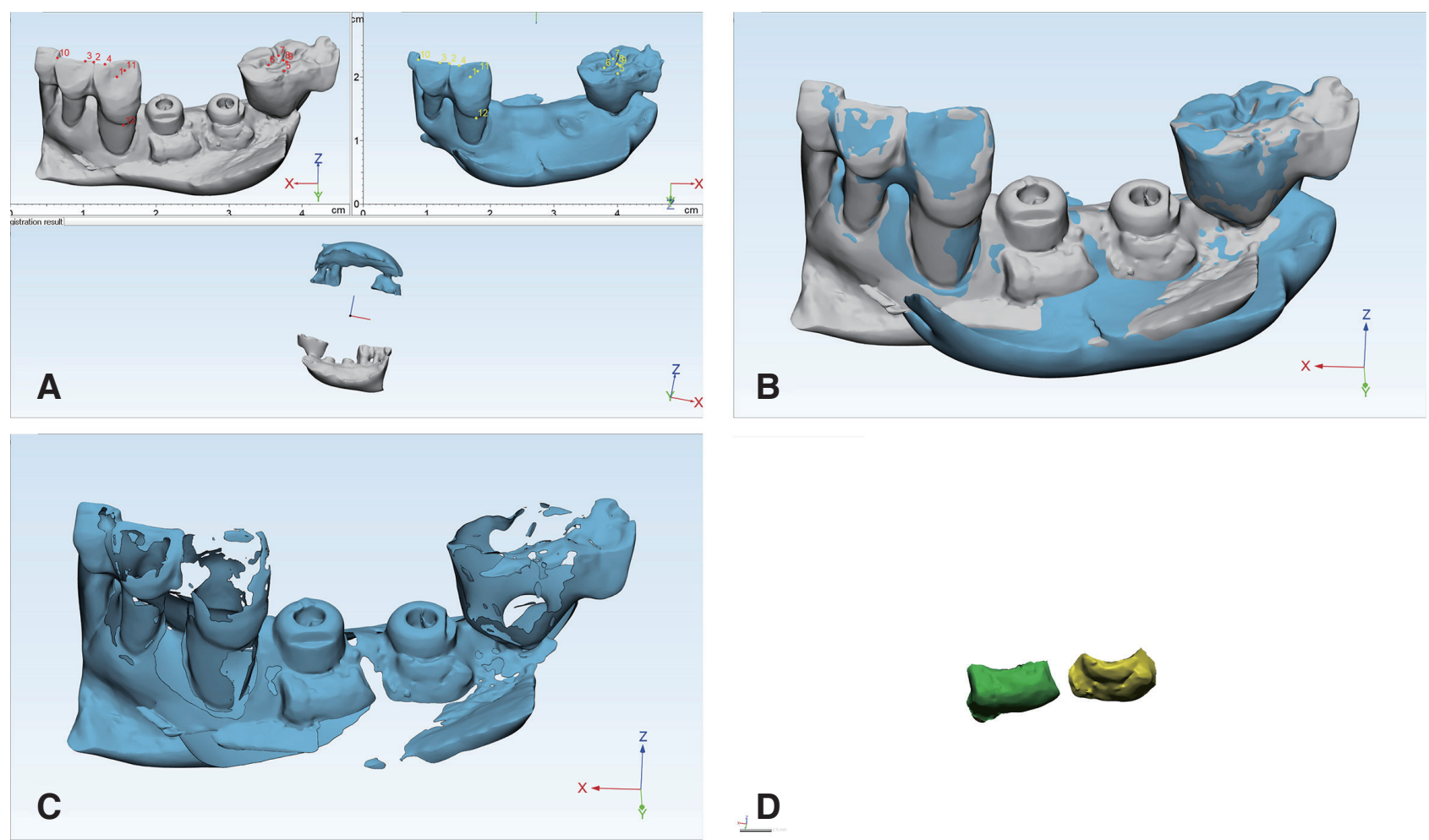

Fig. 4. Measurement of volume change between intraoral scan images. (A) Post-operatvie (white) and pre-operative (blue) scan images were aligned using multiple points of cusp, fossa of adjacent teeth, (B) Aligned scan images, (C) Residual 3D image after Boolean subtraction, (D) Closed spaces indicating volume change of \#34 implant (green, flap folding suture) and \#35 implant (yellow, interrupted suture).

\section{통계 분석}

세 시점(술 후, 봉합사 제거, 3개월 후) 동안 두 봉합 법의 효과를 비교하기 위해 nparLD package를 이용한 nonparametric rank-based method를 이용하여 분석하였 다. Package documentation에 따라 modified ANOVAtype statistic (mATS), ANOVA-type statistic (ATS), Wald-type statistic (WTS) 순으로 우선 순위를 두어 분 석에 참고하였다. 사후 검정으로 Wilcoxon signed-rank test를 이용하여 각 봉합법 군내에서 시점 별로 연조직 부 피 증가를 비교하였다. 유의 수준은 0.05 로 설정하였고, 사후 검정에서는 세 시점에 대한 Bonferroni correction 을 적용하여 $0.05 / 3=0.0167$ 로 설정하였다. 각 통계 분 석은 오픈소스 소프트웨어(RStudio v1.3.1093, RStudio, Boston, USA)를 이용하였다.

\section{결과}

15 명의 환자 모두 중도탈락 없이 3 개월까지 모두 재내 원하여 연구에 참여하였고 특이 소견 없이 안정적인 치유 를 보였다(Fig. 5). 이후 모든 임플란트는 성공적으로 임 플란트 수복의 과정을 거쳐 정기적인 검진 관리 중이다.

시점별 부피 증가량은 술전의 연조직 부피를 기준으로 차감하여 그 차이를 이용하여 비교하였다. 각 시점에서 두 봉합 방법에 따른 연조직 부피 변화량의 중앙값을 비 교 시, 수술 후 3개월 뒤에는 flap folding suture group이, 봉합사 제거 시에는 interrupted suture group이 상대적 으로 연조직 부피의 증강이 높게 나타났다(Table 1). 하 지만 nonparametric rank-based method를 이용하여 연 조직 부피 변화량에 봉합 방법 및 시간이 미치는 효과를 분석 시 두 봉합 방법 간 차이는 통계적으로 유의하지 않 았다 $(P=0.262, \mathrm{mATS})$ (Table 2). 

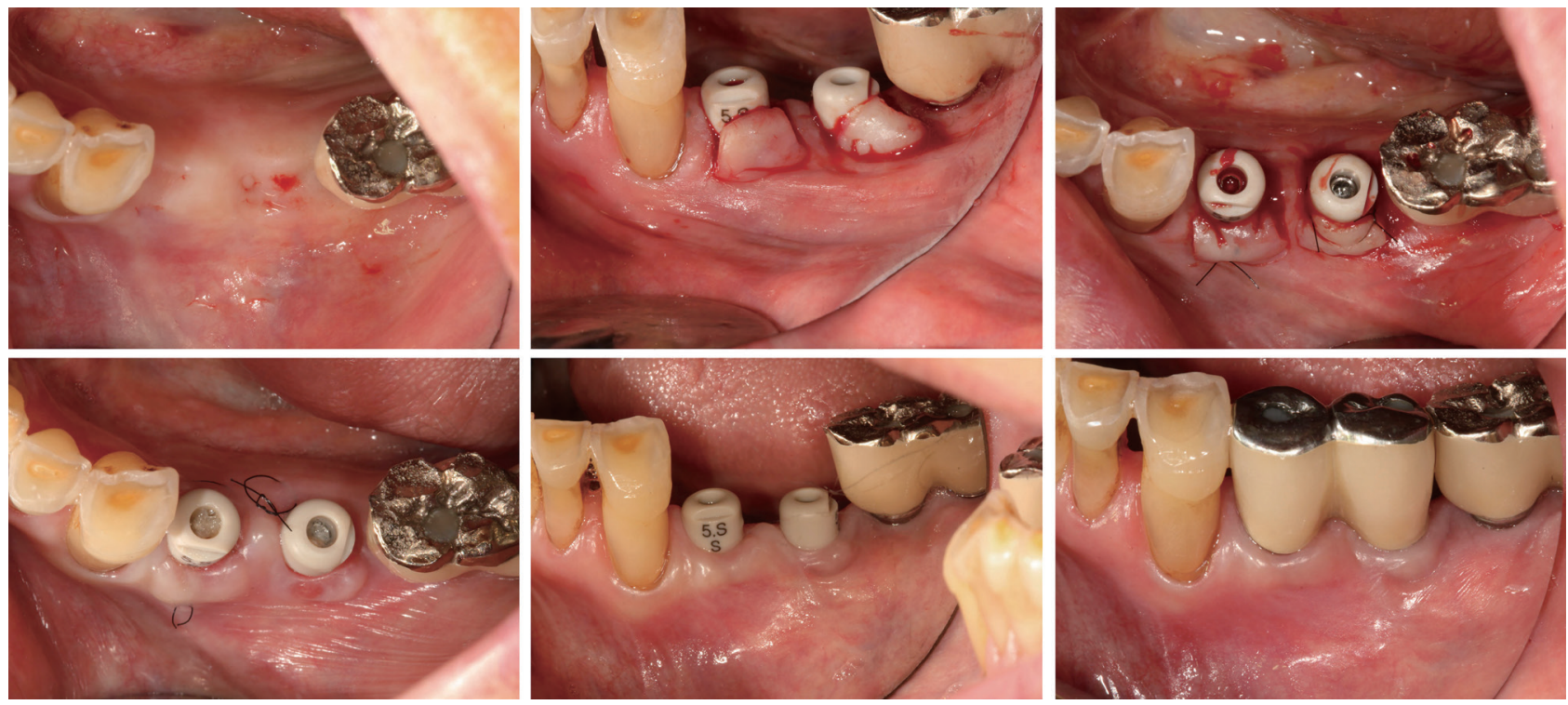

Fig. 5. Representative clinical cases for test and control group. \#34 implant received flap folding suture and \#35 implant received two interrupted sutures. Healing was uneventful and after 2 months of healing period, final restorations were delivered.

Table 1. Soft tissue volume change

\begin{tabular}{lcc}
\hline & Flap folding suture $(\mathrm{n}=9)\left(\mathrm{mm}^{3}\right)$ & Interrupted suture $(\mathrm{n}=9)\left(\mathrm{mm}^{3}\right)$ \\
\hline Post-operation & $45.4[38.8$ to 55.5$]$ & $37.0[30.1$ to 42.1$]$ \\
Stitch out & $26.7[19.5$ to 37.3$]$ & $29.7[17.1$ to 31.1$]$ \\
After 3 months & $14.8[9.4$ to 19.2$]$ & $8.7[8.1$ to 11.4$]$ \\
\hline
\end{tabular}

The change of volume was expressed as median and interquartile range.

Table 2. Nonparametric rank-based analysis using nparLD package

\begin{tabular}{crrrrrrrrr}
\hline & WTS & df & P-value & ATS & df & P-value $\begin{array}{c}\text { mATS for the } \\
\text { whole-plot } \\
\text { factors }\end{array}$ & df1 & df2 & $P$-value \\
\hline Suture & 1.35 & 1 & 0.245 & 1.35 & 1.00 & 0.245 & 1.35 & 1 & 15.94 \\
Time & 152.75 & 2 & $<0.001 *$ & 75.67 & 1.64 & $<0.001 *$ & & & \\
Suture $\times$ Time & 2.83 & 2 & 0.244 & 1.78 & 1.64 & 0.175 & & \\
\hline
\end{tabular}

*: $P<0.05$, WTS: Wald-type statistic, ATS: ANOVA-type statistic, mATS: modified ANOVA-type statistic, df: degree of freedom.

한편 시간에 따른 효과는 유의하게 나타났으며 $(P<$ $0.001, \mathrm{ATS})$. 두 변수간 상호작용은 없었다 $(P=0.175$, ATS). 사후 검정을 통해 각 봉합법별로 군 내에서 세 시 점의 부피 변화량을 비교하였을 때 두 봉합법 모두 술전 과 3 개월 후, 봉합사 제거 시와 3 개월 후 사이에 연조직 부피 증가량이 유의하게 감소하였다(Fig. 6, $P<0.0167$ ).

\section{고찰}

본 연구에서는 단일 임플란트 식립 시 paramarginal flap design을 시행한 후 협측으로 변위된 판막을 치유 지 대주 하방, 협측으로 눌러 고정할 수 있는 형태의 봉합술 인 flap folding suture가 각화점막의 치유에 끼치는 영향 


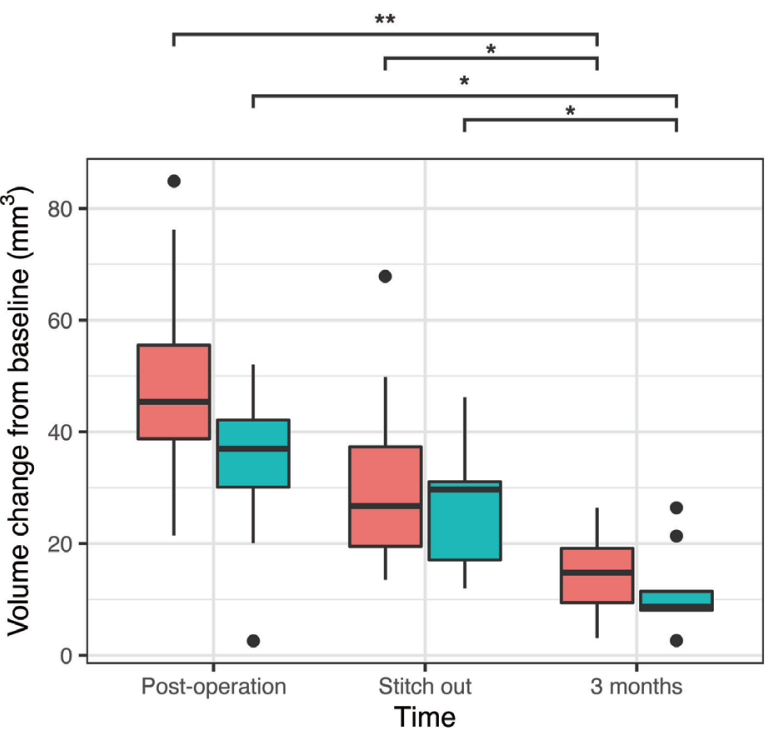

Flap folding suture group 官 Interrupted suture group

Fig. 6. Soft tissue volume change from baseline based on suture technique and time. ${ }^{*}: P<0.0167,{ }^{* *}: P<0.001$ from Wilcoxon signed-rank test for post-hoc analysis. Significance level was adjusted according to Bonferroni correction.

을 비교하였다. 결과적으로 interrupted suture와 대비하 여 flap folding suture를 시행한 실험군에서 3개월 시점 에서 연조직의 증강이 interrupted suture를 시행한 대조 군 대비 더 높게 나타났으나 통계적 유의성은 없었다.

Flap folding suture를 이용한 술식과 비슷한 형태를 가 지는 기존의 roll technique, modified roll technique에서 중요한 과정은 탈상피화(de-epithelization) 과정을 통한 판막의 수정 과정이었다. 만일 상피가 제거되지 않은 채 로 판막이 협측 판막 내부로 밀려 들어가게 되면 오히려 치주낭을 만들어 향후 문제가 발생할 수 있기 때문이다. 반면 본 연구에서 시행한 테크닉에서는 탈상피화 과정이 생략되어 있다. 기존의 roll technique과 달리 판막을 하 방으로 밀어넣는 것이 아니라 치유 지대주의 하방으로 수평적으로 눌러 고정시키는 방식이기 때문이다. 특히 봉 합 후의 판막의 형태를 관찰하면 판막을 말아 넣는 힘보 다는 아래로 눌러 고정시켜주는 힘이 더 큰 것을 볼 수 있 다. 또한 이러한 안정적인 고정 덕분에 2 개의 수직 절개 로 인해 노출된 부위의 치유가 상당히 신속하게 상피화 되는 것을 확인할 수 있었다. 이것은 안정화된 판막이 결 국 혈병의 안정화를 도왔고 그 결과 치유도 안정적으로
진행된 것으로 사료된다.

필자는 이전 연구를 통해 구강내 디지털 스캐너가 가지 는 학술적 가치에 대해 확인한 바 있다. ${ }^{7}$ 이전 연구에서는 수술과 무관한 정상적인 환자의 구내 각화점막을 측정하 였었기에 스캐닝 시 큰 어려움이 없었다. 하지만 이번 연 구는 수술 직후에 스캔을 해야하는 상황이 있었는데 수 술이 끝난 직후에는 출혈 때문에 스캔이 제대로 되지 않 는 어려움이 있었다. 특히 혈액은 고정되어 있지 않고 계 속 움직이는 성질이 있기 때문에 스캐너에서 인지하는 표 면은 계속 변화하는 것으로 나와 부정확도가 올라갈 수 있었다. 따라서 수술 부위의 스캔을 위해서는 최대한 지 혈을 시행하고 동시에 멸균 식염수를 통해 최대한 수술 부위를 세척한 뒤 시행하는 것이 추천된다. 스캐닝 시 출 혈 부위를 좀더 정확하게 스캔할 수 있는 기술의 발전을 도모하면 수술 중 내지는 수술 후 오류가 적은 스캐닝이 가능할 것으로 사료된다.

최근 임플란트 주변의 골 안정성을 위해서는 연조직 의 두께가 중요한 기능을 한다는 연구들이 계속 보고되 고 있다. ${ }^{8-10}$ 이들 연구에서는 $2 \mathrm{~mm}$ 이상의 점막이 치조정 상방에 존재할 경우 골흡수를 최소화 할 수 있다고 보고 하고 있으며 협측 연조직의 두께는 향후 치은 퇴축, 음식 물 저류에 의한 구강 위생의 어려움 등 다양한 문제를 예 방할 수 있다고 지적하고 있다. 이를 예방하기 위해 체적 안정성 콜라겐 비계를 이식하거나 구개측에서 상피하 결 합조직을 채득하여 이식할 수 있는 방법을 활용하고 있 으나 모두 비용적인 문제와 부가적인 수술이 필요하다는 단점이 있다. 이에 paramarginal flap design을 통해 환자 의 자가 조직을 in situ로 활용하여 연조직 증강을 할 수 있다면 큰 장점이 될 수 있다.

일반적으로 치과 영역에서는 단순 봉합술이 가장 보 편적으로 사용되고 있다. 따라서 임플란트 수술과 관련 하여 판막 디자인에 크게 무관하게 습관적으로 단순 봉 합이 시행될 가능성이 높다. 하지만 본 연구에서 사용한 paramarginal flap과 같은 경우는 특히 판막의 가동성이 매우 높고 따라서 판막이 치유 지대주 위로 타고 올라갈 가능성이 매우 높다고 사료된다. 그 결과 각화점막의 폭 이 감소하고 연조직의 부피가 줄어들 위험이 존재한다. 반면 flap folding suture의 경우 판막을 하방으로 눌러주 는 효과가 뛰어나고 판막의 고정 능력이 탁월하기 때문 에 이상적인 치유가 기대된다. 본 연구에서는 이를 디지 털 스캐너를 이용한 부피 측정을 통해 이 효과를 확인할 수 있었다. 
다만 본 연구에서는 제한된 환자 수와 수술 부위의 개 체성으로 인해 통계적 유의성을 확인하는 것은 불가능 하였다. 본 연구는 환자군의 특성상 nonparametric twoway repeated measure ANOVA를 진행하였고 문헌 검 색을 통해 검정을 진행하였다. ${ }^{11} 3$ 개월 시점에서 실험군 의 부피 증강이 높게 나타난 점이 주목할 만하며 nonparametric rank-based analysis에서 시간의 효과가 유의 한 것으로 제시되었다. 사후 검정에서 3 개월 후 두 그룹 에서 유의하게 부피 증가량이 감소한 것을 확인하여 치 유가 안정화된 것을 볼 수 있었다. 이후 randomized controlled clinical study를 통해 좀더 정확한 효과를 확인해 야 할 것으로 사료된다.

\section{결론}

임플란트 주변의 연조직 증강을 위한 flap folding suture 사용의 효과를 디지털 구내 스캐너를 이용하여 임플 란트 식립 전후의 연조직 비교를 본 연구에서 진행하였 다. 통계적 유의성은 없었으나 실험군의 봉합술이 대조 군 대비 3개월 시점에서 연조직 증강에 도움을 준 것으로 사료된다. 향후 좀더 많은 연구가 필요할 것으로 사료된 다.

\section{Acknowledgements}

본 연구는 보건복지부의 재원으로 한국보건산업진흥 원의 보건의료기술연구개발사업의 지원에 의하여 이루 어진 것임(과제 고유 번호: HI20C0129).

\section{ORCID}

Sae-Young Jung https://orcid.org/0000-0002-4926-7254

Dae-Young Kang https://orcid.org/0000-0002-4311-4118

Hyun-Seung Shin https://orcid.org/0000-0002-1410-9731

Jung-Chul Park https://orcid.org/0000-0002-2041-8047

\section{References}

1. Sicilia A, Botticelli D, Working G. Computer-guided implant therapy and soft- and hard-tissue aspects. The Third EAO Consensus Conference 2012. Clin Oral Implants Res 2012;23 Suppl 6:157-61.

2. Wennström JL, Derks J. Is there a need for keratin- ized mucosa around implants to maintain health and tissue stability? Clin Oral Implants Res 2012;23 Suppl 6:136-46.

3. Roccuzzo M, Grasso G, Dalmasso P. Keratinized mucosa around implants in partially edentulous posterior mandible: 10 -year results of a prospective comparative study. Clin Oral Implants Res 2016;27: 491-6.

4. Oh SL, Ji C, Azad S. Free gingival grafts for implants exhibiting a lack of keratinized mucosa: extended follow-up of a randomized controlled trial. J Clin Periodontol 2020;47:777-85.

5. Thoma DS, Lim HC, Paeng KW, Kim MJ, Jung RE, Hämmerle CHF, Jung UW. Augmentation of keratinized tissue at tooth and implant sites by using autogenous grafts and collagen-based soft-tissue substitutes. J Clin Periodontol 2020;47:64-71.

6. Park SH, Wang HL. Pouch roll technique for implant soft tissue augmentation: a variation of the modified roll technique. Int J Periodontics Restorative Dent 2012;32:e116-21.

7. Lim HC, Lee J, Kang DY, Cho IW, Shin HS, Park JC. Digital assessment of gingival dimensions of healthy periodontium. J Clin Med 2021;10:1550.

8. Suárez-López Del Amo F, Lin GH, Monje A, Galindo-Moreno P, Wang HL. Influence of soft tissue thickness on peri-implant marginal bone loss: a systematic review and meta-analysis. J Periodontol 2016;87:690-9.

9. Linkevicius T, Apse P, Grybauskas S, Puisys A. Reaction of crestal bone around implants depending on mucosal tissue thickness. A 1-year prospective clinical study. Stomatologija 2009;11:83-91.

10. Puisys A, Linkevicius T. The influence of mucosal tissue thickening on crestal bone stability around bone-level implants. A prospective controlled clinical trial. Clin Oral Implants Res 2015;26:123-9.

11. Noguchi K, Gel YR, Brunner E, Konietschke F. nparLD: An R software package for the nonparametric analysis of longitudinal data in factorial experiments. J Stat Softw 2012;50(12). 


\section{Flap folding suture를 활용한 판막의 고정에 따른 임플란트 주변 연조직 3차원 부피 변화 관찰}

정세영 ${ }^{1 \dagger}$ 대학원생, 강대영 ${ }^{2 \dagger}$ 임상 조교수, 신현승 ${ }^{1}$ 부교수, 박정철 ${ }^{1 *}$ 부교수

${ }^{1}$ 단국대학교 치과대학 치주과학교실

${ }^{2}$ 단국대학교 치과대학 치과병원 치주과

목적: 다양한 봉합술을 통해 임플란트 주변에 최적화된 각화점막을 확보하려는 시도가 진행되었다. 본 연구의 목적은 임 플란트 식립 후 2 개의 서로 다른 봉합술 시행 후 연조직의 치유 양상을 평가하는 것이다.

연구 재료 및 방법: 15 명의 환자에서 18 개의 임플란트가 식립되었고 연구에 포함되었다. 부가적인 골이식 없이 단순 임플 란트 식립만 진행하였다. 2개의 서로 다른 봉합술을 이용해 paramarginal flap design을 시행한 협측 판막을 임플란트 치 유 지대주 하방으로 고정하였다. 디지털 구내 스캐너를 이용하여 초진, 수술 직후, 발사, 3개월 시점에 스캔을 진행하였 다. 각 시점에 따른 스캔 데이터를 인접치의 교두, 소와, 치유지대주 등의 여러 점들을 기준으로 초진 데이터와 중첩하였 다. 각 시점의 스캔 데이터를 초진 데이터와 subtraction한 다음 임플란트 주위 연조직의 증가량에 해당하는 폐곡면의 부 피를 측정하였다. 폐곡면의 부피는 $\mathrm{mm}^{3}$ 단위로 계측하였다. 3 개 시점에서 2 개의 서로 다른 봉합술에 의한 부피 변화를 비교하기 위해 nonparametric rank-based 분석을 시행하였다.

결과: 양쪽 군 모두 치유는 양호하였다. 양쪽 봉합군은 수술 후 즉시 연조직 부피의 증가를 보여주었다. 3 개월에 걸쳐 부피는 시간에 따라 유의성 있게 감소하였다 $(P<0.001)$. Flap folding suture 군의 연조직 부피는 3개월 시점에서 interrupted suture 군보다 더욱 높은 중앙값을 보였으나 통계적 유의성은 없었다 $(P>0.05)$.

결론: 임플란트 시행 시 paramarginal flap 형태로 거상된 판막을 flap folding suture로 고정한 군은 3개월 치유 기간 후 interrupted suture 군보다 더욱 높은 연조직 증강 수치를 보였다. 하지만 좀더 장기적인 관찰 연구가 필요할 것으로 사료 된다.

(구강회복응용과학지 2021;37(3):130-7)

주요어: 치과 임플란트; 각화점막; 구내 스캐너; 임상연구

*교신저자: 박정철

(31116) 충청남도 천안시 동남구 단대로 119 단국대학교 치과대학 치주과

Tel: 041-550-1931 | Fax: 0303-3442-7364 | E-mail: back2thesuture@gmail.com

접수일: 2021년 9월 1일 | 수정일: 2021년 9월 7일 | 채택일: 2021년 9월 7일

†공동 제 1 저자. 